\title{
Face mask fit modifications that improve source control performance
}

Francoise M. Blachere ${ }^{a}$, Angela R. Lemons ${ }^{a}$, Jayme P. Coyle ${ }^{a}$, Raymond C. Derk ${ }^{a}$, William G. Lindsley ${ }^{a}$, Donald H. Beezhold ${ }^{a}$, Karen Woodfork ${ }^{b, d}$, Matthew G. Duling ${ }^{c}$, Brenda Boutin ${ }^{c}$, Theresa Boots $^{a}$, James R. Harris ${ }^{c}$, Tim Nurkiewicz ${ }^{b, d}$, and John D. Noti ${ }^{a}$

${ }^{a}$ Health Effects Laboratory Division, National Institute for Occupational Safety and Health, Centers for Disease Control and Prevention, Morgantown, West Virginia, USA

${ }^{b}$ Department of Physiology and Pharmacology, West Virginia University School of Medicine, Morgantown, West Virginia, USA

${ }^{c}$ National Personal Protective Technology Laboratory, National Institute for Occupational Safety and Health, Centers for Disease Control and Prevention, Morgantown, West Virginia, USA

${ }^{d}$ Center for Inhalation Toxicology, West Virginia University School of Medicine, Morgantown, West Virginia, USA

Corresponding author:

Francoise M. Blachere, MS

National Institute for Occupational Safety and Health (NIOSH)

1000 Frederick Lane, M/S 4020

Morgantown, WV 26508-5402

Email: FBlachere@cdc.gov 
medRxiv preprint doi: https://doi.org/10.1101/2021.09.16.21263642; this version posted September 26, 2021. The copyright holder for this preprint (which was not certified by peer review) is the author/funder, who has granted medRxiv a license to display the preprint in perpetuity.

This article is a US Government work. It is not subject to copyright under 17 USC 105 and is also made available for use under a CCO license.

\section{BACKGROUND}

During the COVID-19 pandemic, face masks are used as source control devices to reduce the expulsion of respiratory aerosols from infected people. Modifications such as mask braces, earloop straps, knotting and tucking, and double masking have been proposed to improve mask fit. However, the data on source control are limited.

\section{METHODS}

The effectiveness of mask fit modifications was determined by conducting fit tests on human subjects and simulator manikins and by performing simulated coughs and exhalations using a source control measurement system.

\section{RESULTS}

Medical masks without modification blocked $\geq 56 \%$ of cough aerosols and $\geq 42 \%$ of exhaled aerosols. Modifying fit by crossing the earloops or placing a bracket under the mask did not increase performance, while using earloop toggles, an earloop strap, and knotting and tucking the mask increased performance. The most effective modifications for improving source control performance were double masking and using a mask brace. Placing a cloth mask over a medical mask blocked $\geq 85 \%$ of cough aerosols and $\geq 91 \%$ of exhaled aerosols. Placing a brace over a medical mask blocked $\geq 95 \%$ of cough aerosols and $\geq 99 \%$ of exhaled aerosols.

\section{CONCLUSION}

Fit modifications can greatly improve the performance of face masks as source control devices for respiratory aerosols.

Keywords: Face mask, fit modification, respiratory aerosols, source control. 
medRxiv preprint doi: https://doi.org/10.1101/2021.09.16.21263642; this version posted September 26, 2021. The copyright holder for this preprint (which was not certified by peer review) is the author/funder, who has granted medRxiv a license to display the preprint in perpetuity. This article is a US Government work. It is not subject to copyright under 17 USC 105 and is also made available for use under a CCO license.

\section{BACKGROUND}

SARS-CoV-2 is a highly infectious respiratory virus that is primarily transmitted by respiratory aerosols and droplets emitted during activities such as talking, breathing, and coughing. ${ }^{1,2}$ In the past, aerosols have been defined as airborne particles $<5 \mu \mathrm{m}$ in diameter while droplets are $>5 \mu \mathrm{m}$, but more recent work based on aerosol physics defines aerosols as $<100 \mu \mathrm{m}$ with droplets being $>100 \mu \mathrm{m} .^{2}$ Several factors influence SARS-CoV-2 transmissibility, including particle size, a recipient's inhalation exposure, and their susceptibility. ${ }^{3}$ Because symptomatic and asymptomatic individuals infected with SARS-CoV-2 can exhibit a high viral load in their respiratory fluids, ${ }^{4}$ the $\operatorname{CDC}$ recommends that unvaccinated people wear a face mask that covers the nose and mouth while indoors to reduce community transmission during the COVID-19 pandemic. ${ }^{5}$ Fully vaccinated individuals are also advised to wear a face mask indoors, particularly in areas of substantial or high COVID-19 transmission. ${ }^{5}$ Wearing a face mask to protect others from potentially infectious aerosols and droplets, called source control, has been shown to be a highly effective infection control strategy to limit the spread of COVID-19. ${ }^{6,7}$ Face masks provide a physical barrier to the expulsion of both aerosols and droplets, and offer limited personal respiratory protection against aerosols that may enter through the nose and mouth. ${ }^{8-10}$

As a result of the COVID-19 pandemic, the consumer market has been flooded with a wide variety of face coverings and masks that vary in fit, material, and design. To provide guidance on products that are neither a medical mask (e.g., surgical masks) as per specification F2100 for providing source control nor a respirator for providing inhalation protection (e.g. N95 respirators), ASTM International developed a standard specification for barrier face coverings (F3502) to establish a baseline on mask performance using standards including submicron particulate filtration and airflow resistance (breathability).$^{11}$ Epidemiological, clinical, and modelling studies on the community use of face masks show a significant reduction in COVID-19 transmission, ${ }^{7,12-14}$ yet the data on source control performance and the level of respiratory protection are limited. Recent laboratory studies using a 
medRxiv preprint doi: https://doi.org/10.1101/2021.09.16.21263642; this version posted September 26, 2021. The copyright holder for this preprint (which was not certified by peer review) is the author/funder, who has granted medRxiv a license to display the preprint in perpetuity. This article is a US Government work. It is not subject to copyright under 17 USC 105 and is also made available for use under a CCO license.

respiratory aerosol simulator tested several medical masks, cloth masks, and neck gaiters, and found a $40-60 \%$ reduction in the expulsion of cough aerosols. ${ }^{8}$ Analogous studies using a coughing (source) and breathing (recipient) simulator inside an aerosol exposure chamber demonstrated a $96 \%$ reduction in aerosol exposure to the recipient when both simulators were double masked. ${ }^{9}$

To limit the transmission of SARS-CoV-2, the CDC recommends wearing a multi-layer, well-fitted face mask that forms a tight seal between the face and the mask. ${ }^{15}$ The presence of face seal leaks enables respiratory aerosols to escape out rather than pass through the filtering materials of the mask, consequently reducing the benefits of wearing a face mask for source control. Because medical and cloth masks tend to fit more loosely than a fitted respirator ${ }^{16}$, recent attention has been given to modifications that improve mask fit. Aerosol exposure simulation studies by our group looking at the effect of knotting the earloops and tucking in the pleats of a medical mask or wearing a cloth mask over a medical mask (double masking) showed a significant reduction in exposure when compared to not wearing a mask or wearing a medical mask without any modification. ${ }^{9}$ A publication by Clapp et al. evaluated several popular modifications and found that fitting a medical mask with either a sleeve of hosiery or multiple rubber bands, or adjusting the ear loops with either a claw-like hair clip or a 3D printed ear guard, increased particle filtration to the wearer. ${ }^{17}$ Utilizing the Wells-Riley equation to mathematically predict the probability of airborne disease exposure, research by Rothamer et al. demonstrated that a poorly fitting mask diminished particle filtration, but that the addition of an elastic, frame-like mask fitter improved source control performance by reducing leaks around a mask. ${ }^{18}$ For this study, our group evaluated various modifications that aimed to improve the fit of a medical or cloth face mask and reduce the amount of expelled aerosols during simulated coughs and exhalations.

\section{MATERIALS AND METHODS}

\section{Face masks and modifications}


medRxiv preprint doi: https://doi.org/10.1101/2021.09.16.21263642; this version posted September 26, 2021. The copyright holder for this preprint (which was not certified by peer review) is the author/funder, who has granted medRxiv a license to display the preprint in perpetuity. This article is a US Government work. It is not subject to copyright under 17 USC 105 and is also made available for use under a CCO license.

Studies were conducted from January 2021 through April 2021. The commercially available face masks assessed in this study included two medical masks and three cloth masks of different material (polyester blend or cotton) and ply (Table 1). Tested fit modifications, also commercially available, included a mask bracket, an earloop strap, earloop toggles, and a mask brace (Table 1). Additional fit modifications included double masking, where a 3-ply cloth mask was worn over a medical face mask; crossing the earloops; and knotting \& tucking, where the earloops are knotted and the mask pleats are tucked under the knotted loop. More details on the masks and fit modifications used can be found in Supplemental Figures S1 and S2.

\section{Filtration efficiency and inhalation airflow resistance}

ASTM standardized tests for filtration efficiency and inhalation airflow resistance measurements from unmodified medical and cloth face masks were performed using automated filter testers (Models 8130 and $8130 \mathrm{~A}, \mathrm{TSI}$ ) as previously described. ${ }^{10}$ Briefly, medical and cloth face masks were secured to a test plate using beeswax. Pleats on the unmodified medical face masks were expanded prior to measurement. Filtration efficiency and airflow resistance were measured on the double-mask modification by securing the edges of a 3-ply cloth mask over the edges of a medical face mask with beeswax. Filtration efficiency and airflow resistance were not measured on face masks with crossed earloops, mask brackets, earloop straps, earloop toggles, knotted and tucked earloops, or mask braces, as these fit modifications do not alter the performance of the materials used in the construction of a mask.

\section{Fit testing}

Fit factor assessment, which measures the degree to which aerosols can enter through face seal leaks on a mask, was performed using the PortaCount Pro+ respirator fit tester as previously described. ${ }^{10}$ Reported fit values are reflective of the ratio of the aerosol concentration outside the face mask to the 
medRxiv preprint doi: https://doi.org/10.1101/2021.09.16.21263642; this version posted September 26, 2021. The copyright holder for this preprint (which was not certified by peer review) is the author/funder, who has granted medRxiv a license to display the preprint in perpetuity. This article is a US Government work. It is not subject to copyright under 17 USC 105 and is also made available for use under a CCO license.

aerosol concentration inside the face mask. ${ }^{10}$ For fit tests on human subjects, a sample group of 4 subjects participated in the study. Face masks with and without modification were fit tested on human subjects ( $n=3-4$ tests/modification) with a PortaCount ${ }^{\circledR}$ Pro+ (model 8038, TSI Corporation; Shoreview, MN) in N99 mode using the Occupational Safety and Health Administration (OSHA) modified ambient aerosol condensation nuclei counter (CNC) protocol for filtering facepiece respirators. ${ }^{19}$ Because only fit factors were measured and no identifiable information was collected, the West Virginia University Office of Human Research Protections determined that Institutional Review Board approval was not required for this study. This activity was reviewed by CDC and was conducted consistent with applicable federal law and CDC policy (see e.g., 45 C.F.R. part 46; 21 C.F.R. part 56; 42 U.S.C. §241(d), 5 U.S.C. §552a, 44 U.S.C. $\$ 3501$ et seq.). Simulator manikins were fit tested with each mask fit modification ( $n=4-5$ tests/modification) using a PortaCount ${ }^{\circledR}$ Pro+ (Model 8038, TSI Corporation; Shoreview, MN) in N99 mode as per manufacturer's instructions. A constant breathing rate of $36 \mathrm{~L} / \mathrm{min}$ was used for all simulator fit tests and a daily quality assurance test was conducted using a 3M 1860 N95 respirator.

\section{Source control measurement}

A source control measurement system (Supplemental Figure S3) was used as previously described to measure the collection efficiencies (\% particles blocked) for coughed or exhaled aerosols by fit modified or unmodified face masks. ${ }^{8,10}$ Briefly, a test aerosol solution consisting of $14 \%$ potassium chloride (KCl) and $0.4 \%$ sodium fluorescein (particle size range from $0-20 \mu \mathrm{m}$ in diameter) was propelled through the mouth of an elastomeric headform outfitted with a mask (with modification or without modification) during simulated coughs ( $4.2 \mathrm{~L}$ volume) and breathing $(15 \mathrm{~L} / \mathrm{min})$ into a $136 \mathrm{~L}$ collection chamber. Each face mask (unmodified or modified) was used for two consecutive tests with a total of four experimental replicates performed under the set experimental conditions for simulated cough and exhalations. The performance of a 3M $1860 \mathrm{~N} 95$ respirator as a source control device was also included in this study for metric comparisons. The test aerosol collected from control experiments without a mask had a total 
medRxiv preprint doi: https://doi.org/10.1101/2021.09.16.21263642; this version posted September 26, 2021. The copyright holder for this preprint (which was not certified by peer review) is the author/funder, who has granted medRxiv a license to display the preprint in perpetuity. This article is a US Government work. It is not subject to copyright under 17 USC 105 and is also made available for use under a CCO license.

mass of $525 \mu \mathrm{g}$ (cough) and $495 \mu \mathrm{g}$ (exhalation). An Anderson Impactor operating at $28.3 \mathrm{~L} / \mathrm{min}$ was used to collect and separate the test aerosol into seven particle size fractions by their aerodynamic diameter: $<0.6 \mu \mathrm{m} ; 0.6-1.1 \mu \mathrm{m} ; 1.1-2.1 \mu \mathrm{m} ; 2.1-3.3 \mu \mathrm{m} ; 3.3-4.7 \mu \mathrm{m}, 4.7-7.0 \mu \mathrm{m}$; and $>7 \mu \mathrm{m}$. Because of possible losses from settling, particle data for the $>7 \mu \mathrm{m}$ size fraction $(<0.7 \%$ of the total test aerosol mass) was not included in the collection analysis.

\section{Exposure reduction studies}

Respiratory exposure studies were performed using a simulator that expels a test aerosol (the source) and a breathing simulator (the recipient) inside an experimental chamber as previously described. ${ }^{9,20}$ Briefly, a medical face mask or cloth mask (with or without fit modification) was placed on the source simulator situated 6 feet from the recipient simulator. An optical particle counter (Grimm 1.108; Aerosol Technik Ainring GmbH \& Co. KG; Ainring, Germany) was used to measure the aerosol concentration at the mouth of an unmasked recipient simulator. Exposure was assessed by comparing the mean mass aerosol concentration measured at the mouth of the unmasked recipient when no mask was worn by the source simulator compared when a fit modified medical or cloth mask was worn.

\section{Statistical analysis}

Mask source control performance was assessed by calculating the collection efficiency as (1$\left.M_{\text {mask }} / M_{\text {control }}\right)$, where $M_{\text {mask }}=$ total mass of the aerosol particles that passed through or around the fit modified source control device and was collected by the impactor and $\mathrm{M}_{\text {control }}=$ total mass of the aerosol particles expelled by the source control measurement system without a face mask and collected by the impactor. To test for significance for cloth mask types that only had one type of modification versus the control, the Wilcoxon rank sum test was used. For mask types that contained more than 1 level of fit modification, overall significance was first assessed using the Kruskal-Wallis test. Pairwise comparisons were then made using the Wilcoxon rank sum test and p-values were adjusted using the Benjamini, 
medRxiv preprint doi: https://doi.org/10.1101/2021.09.16.21263642; this version posted September 26, 2021. The copyright holder for this preprint (which was not certified by peer review) is the author/funder, who has granted medRxiv a license to display the preprint in perpetuity.

This article is a US Government work. It is not subject to copyright under 17 USC 105 and is also made available for use under a CCO license.

Hochberg, and Youkilis method to control the false discovery rate to compare each fit modification to the unmodified mask control. The percent change in collection efficiency was considered significant if $p$ $\leq 0.05$. Fit factor, filtration efficiency, and inhalation airflow resistance data were analyzed using a pairwise Wilcoxon rank sum test followed by a Benjamini-Hochberg correction for multiple comparisons. Each fit modification method was compared to the unmodified mask control. Differences were considered significant at a $p \leq 0.05$. All statistical analyses were performed using R Statistical Environment v. 4.0.2 (The R Foundation, Vienna, Austria).

\section{RESULTS}

\section{Filtration efficiencies and inhalation airflow resistance}

Filtration efficiency and inhalation airflow resistance measurements show differences between the material and ply level of medical and cloth face masks (Supplemental Table ST1). Medical mask 1 had a filtration efficiency of $82.0 \%$ and an airflow resistance of $45.4 \mathrm{~Pa}$ whereas medical mask 2 had a filtration efficiency of $96.4 \%$ and an airflow resistance of $63.7 \mathrm{~Pa}$. The combination of a 3-ply cloth mask over medical mask 1 demonstrated a similar filtration efficiency of 83.3\%, but airflow resistance increased to 98.7 Pa. Likewise, medical mask 2 doubled with a 3-ply cloth mask had a filtration efficiency of $95.5 \%$ but airflow resistance increased to $97.1 \mathrm{~Pa}$. The filtration performance for cloth face masks was 2 to 4 fold lower than that of the medical masks and airflow resistance was generally higher. The 2-ply cloth mask exhibited a filtration efficiency of $20.2 \%$ and an airflow resistance of 96.4 Pa while the 3-ply mask had a filtration efficiency of $21.0 \%$ and an airflow resistance $45.1 \mathrm{~Pa}$. The 4-ply cloth mask had an elevated filtration efficiency of $36.0 \%$ and an airflow resistance of $92.2 \mathrm{~Pa}$.

\section{Human and manikin fit tests}


medRxiv preprint doi: https://doi.org/10.1101/2021.09.16.21263642; this version posted September 26, 2021. The copyright holder for this preprint (which was not certified by peer review) is the author/funder, who has granted medRxiv a license to display the preprint in perpetuity. This article is a US Government work. It is not subject to copyright under 17 USC 105 and is also made available for use under a CCO license.

To assess mask fit with and without modification, quantitative fit testing was performed on human subjects and on the simulator manikin (Table 2). The average human fit factor for medical mask 1 was 1.6, while medical mask 2 had an average fit factor of 1.8; these results are consistent with previous studies that reported human fit factors of 1.0 to 2.4 for medical and cloth face masks. ${ }^{10}$ Crossing the earloops or using a mask bracket decreased the fit factor of both medical masks. The remaining fit modifications increased the fit factor, with the mask brace demonstrating the greatest increase to 7.2 for medical mask 1 and 13.3 for medical mask 2. Increases in fit factor were also observed when the mask brace was secured over a cloth mask, with the 4-ply cloth mask demonstrating a 3-fold increase in fit factor.

When fitted with a medical mask, the average manikin fit factor was 2.0 for medical mask 1 and 2.9 for medical mask 2 (Table 2). As was observed in human fit testing, crossing the earloops decreased the fit factor for medical mask 2 on the manikin. Some modifications, such as double masking and donning a mask brace, demonstrated a 2.4 to $3.3-$ fold increase in mask fit. An increase in mask fit was also observed when the mask brace was secured over a cloth mask, with the 3-ply and 4-ply cloth masks demonstrating a 1.4-fold increase in fit factor.

\section{Source control simulation studies}

Using the source control measurement system, the efficacies of unmodified and fit modified face masks at collecting aerosol particles expelled during simulated coughs and exhalations are presented in Figure 1. The mean particle collection efficiency of medical mask 1 without modification was $56.0 \%$ for coughing and $42.0 \%$ for exhalations, while medical mask 2 had a collection efficiency of $63.0 \%$ for coughing and $55.0 \%$ for exhalation. Crossing the earloops on a medical face mask or using a mask bracket did not significantly improve the source control performance. Increasing tension to the earloops with an adjustable strap significantly improved the collection efficiencies of both medical masks during 
medRxiv preprint doi: https://doi.org/10.1101/2021.09.16.21263642; this version posted September 26, 2021. The copyright holder for this preprint (which was not certified by peer review) is the author/funder, who has granted medRxiv a license to display the preprint in perpetuity. This article is a US Government work. It is not subject to copyright under 17 USC 105 and is also made available for use under a CCO license.

cough experiments to $72.0 \%$ for medical mask 1 and $75.0 \%$ for medical mask 2 . The strap modification also significantly improved the collection efficiency of medical mask 1 during simulated exhalation but did not change the performance of medical mask 2. Modifications to the earloops by adding toggles or by knotting and tucking achieved similar increases in source control performance to greater than $74 \%$ for both medical masks tested. Fit modifications that produced the most significant improvement to the source control performance of a medical face mask were double masking with a cloth mask over the medical mask and the use of a mask brace. Particle collection efficiencies for double masking with medical mask 1 were $85.0 \%$ during experimental coughs and 92\% during exhalation, while doubling masking with medical mask 2 demonstrated collection efficiencies upward of 92\% (cough) and 91\% (exhalation). When using a mask brace over medical mask 1 or medical mask 2, average collection efficiencies of $95 \%$ for coughs and $99 \%$ for exhalations were obtained.

Respiratory viruses are transmitted by droplets and aerosols in a broad range of particle sizes. ${ }^{13}$ Reduced source control performance with an unmodified medical mask was largely due to a lower collection efficiency for particles $\leq 3.3 \mu \mathrm{m}$ in size. Medical face masks blocked $53-60 \%$ of expelled particles $\leq 3.3 \mu \mathrm{m}$ during simulated coughs but blocked upwards of $80 \%$ of the particles sized $>3.3 \mu \mathrm{m}$ (Figure 2). Similar trends were observed following simulated exhalation experiments with $40-54 \%$ of particles $\leq 3.3 \mu \mathrm{m}$ and $62-71 \%$ of particles $>3.3 \mu \mathrm{m}$ collected. Fit modifying a medical mask by crossing the earloops, adding a bracket, or using an earloop strap did not increase the collection efficiency of particles in either size range. However, the other fit modifications improved the collection efficiency of particles, particularly those in the $\leq 3.3 \mu \mathrm{m}$ range. The most marked improvement for particles $\leq 3.3 \mu \mathrm{m}$ was observed following addition of the mask brace, where a collection efficiency of nearly $100 \%$ was obtained by securing either type of medical mask with the elastic brace. 
medRxiv preprint doi: https://doi.org/10.1101/2021.09.16.21263642; this version posted September 26, 2021. The copyright holder for this preprint (which was not certified by peer review) is the author/funder, who has granted medRxiv a license to display the preprint in perpetuity. This article is a US Government work. It is not subject to copyright under 17 USC 105 and is also made available for use under a CCO license.

Source control performance of fit modified cloth face masks with a mask brace demonstrated significant improvements in particle collection during simulated coughs and exhalations (Figure 1). The collection efficiency of an unmodified cloth mask tested during cough simulations ranged from $42 \%$ for the 2-ply cloth mask to $51 \%$ for the 3-ply cloth mask and $71 \%$ for a 4 -ply cloth mask. Similarly, increasing the number of cloth layers increased the collection efficiency during simulated exhalation, with values of $36 \%$ for the 2 -ply cloth mask, $44 \%$ for the 3-ply cloth mask, and $62 \%$ for the 4 -ply cloth mask. Securing a 4-ply cloth mask with a mask brace further increased the collection efficiency from $71 \%$ to $91 \%$ during simulated coughs, and from $62 \%$ to $92 \%$ during simulated exhalation. An increase in collection efficiency was also observed when securing the mask brace over the 3-ply cloth mask.

When looking at the collection efficiency of cloth masks for particles $\leq 3.3 \mu \mathrm{m}$ in size, neither a 2ply nor 3-ply cloth mask performed to the level of a 4-ply mask (results not shown). The percentage of particles blocked by a 4-ply cloth mask are presented in Figure 2. Results were similar to what was observed following fit modification of a medical mask with a mask brace. The addition of a mask brace over the 4-ply cloth mask demonstrated a marked improvement when collecting particles $\leq 3.3 \mu \mathrm{m}$ in size, with up to $88 \%$ and $90 \%$ blocked during simulated coughs and exhalation, respectively. For particles sized $>3.3 \mu \mathrm{m}$, the mask brace increased the collection efficiency of a 4-ply cloth mask from $92 \%$ to $98 \%$ during simulated coughs, and from $91 \%$ to $99 \%$ during simulated exhalation.

\section{Exposure reduction studies}

Simulated particle exposure studies examining the performance of fit modified medical and cloth face masks are presented in Figure 3. In these studies, particles were exhaled by a masked source simulator and the mass of the particles reaching the mouth of an unmasked recipient breathing simulator was measured. The reduction in exposure to airborne particles seen in these experiments were similar to the particle collection efficiencies measured with the source control system. Likewise, significant increases 
medRxiv preprint doi: https://doi.org/10.1101/2021.09.16.21263642; this version posted September 26, 2021. The copyright holder for this preprint (which was not certified by peer review) is the author/funder, who has granted medRxiv a license to display the preprint in perpetuity. This article is a US Government work. It is not subject to copyright under 17 USC 105 and is also made available for use under a CCO license.

in particle blocking were obtained when the source simulator wore a medical mask fit modified with earloop toggles, knotted and tucked earloops, or a mask brace. Results show that greater than $98 \%$ of the particle mass was blocked by a medical face mask fit modified with a brace and are comparable to the source control performance of an N95 respirator. ${ }^{8}$ While the mask brace appeared to improve the percentage of particles blocked by a 2-ply and 3-ply cloth mask, the increase was not statistically significant.

\section{DISCUSSION}

SARS-CoV-2 is transmissible through expelled respiratory droplets and aerosols. Although the relative contribution of droplets and aerosols to COVID-19 cases remains unclear, the use of face masks is an important source control measure that reduces the expulsion of these respiratory droplets and aerosols and helps slow the spread of SARS-CoV-2. ${ }^{21}$ Over the course of the COVID-19 pandemic, several modifications have been suggested by media outlets to improve the comfort or fit of face masks, but little information is available as to how these fit modifications affect the source control performance of face masks. Although fit testing is an OSHA requirement used for assessing seal leakages on tight fitting respiratory protective devices such as N95 respirators and filtering facepiece respirators, ${ }^{19}$ fit tests of medical masks show that crossing the earloops or using a mask bracket generally diminishes the fit factor on both the simulator manikin as well as on human subjects. On the other hand, use of earloop toggles or a mask brace created a better seal and improved the fit of medical masks. The mask brace also significantly improved the fit of cloth face masks on human subjects. In general, greater fit factors were observed with the pliable headform used in our respiratory simulation studies compared to human subjects. These noted differences are consistent with previous studies by our group and likely relate to the fit test protocol and facial variations that alter how well a mask seals to the face. ${ }^{10}$ When measuring mask fit factor, human test subjects performed the series of test exercises outlined by the CNC fit test 
medRxiv preprint doi: https://doi.org/10.1101/2021.09.16.21263642; this version posted September 26, 2021. The copyright holder for this preprint (which was not certified by peer review) is the author/funder, who has granted medRxiv a license to display the preprint in perpetuity. This article is a US Government work. It is not subject to copyright under 17 USC 105 and is also made available for use under a CCO license.

protocol ${ }^{19}$ whereas the manikin simulators used in this study are static and also breathed at a constant rate.

Using the source control measurement system, our quantitative lab-based studies demonstrate that not all fit modifications improve mask source control performance. While advertised to create more breathing space, the use of a mask bracket with a medical mask was found to reduce the total mass of particles collected compared with an unmodified medical mask. Visible face seal gaps along the cheeks of the manikin were evident when the mask bracket was inserted under a medical face mask (Supplemental Figure S1), enabling expelled aerosols to flow into the collection chamber. In comparison, a strap, toggles, or knotted and tucked fit modifications created a better mask seal to the simulator headform and enhanced the source control performance of a medical face mask. Likewise, double masking with a 3-ply cloth mask or use of a mask brace over a medical face mask created a tighter seal and significantly improved particle collection efficiencies.

Although the source control measurement system is unable to separate out the effects of multiple variables within each mask type, simulation studies examining the performance of unmodified and fit modified face masks demonstrate that fabric composition and ply level greatly affect source control performance. A greater percentage of expelled particles were blocked by an unmodified 4-ply cloth mask in comparison to an unmodified 3-ply cloth mask. These results support previous findings by our group examining performance metrics for cloth face masks as source control devices. ${ }^{10}$ In this current study, we found that an unmodified 4-ply cloth mask had a higher particle collection efficiency compared with an unmodified medical face mask, but a brace-modified 4-ply cloth mask did not perform to the level of a brace-modified medical face mask. The presence of seal leaks as a result of poor mask fit is a likely explanation for this discrepancy. Results from our simulation studies examining the double masking modification, where a 3-ply cloth mask was layered over a medical face mask, show that collection efficiencies increased when a tighter seal was attained on a medical mask. Consequently, 
medRxiv preprint doi: https://doi.org/10.1101/2021.09.16.21263642; this version posted September 26, 2021. The copyright holder for this preprint (which was not certified by peer review) is the author/funder, who has granted medRxiv a license to display the preprint in perpetuity. This article is a US Government work. It is not subject to copyright under 17 USC 105 and is also made available for use under a CCO license.

layering two loose fitting medical masks would neither reduce seal leaks nor improve source control performance.

Filtration efficiency studies examining the intrinsic properties of the materials used in cloth face masks have shown that fabrics with tight weaves and low porosity, and the use of multiple layers and fabric combinations (cotton polyester blends), can effectively filter aerosol particles in the $10 \mathrm{~nm}$ to 10 $\mu \mathrm{m}$ size range. ${ }^{22}$ While mask filtration efficiency as well as airflow resistance measurements are neither reflective of mask fit nor source control performance, our study results provide supporting evidence that the materials used in the cloth mask do not filter particles to the level of the materials used in a medical face mask. When looking at inhalation airflow resistance, the assessed 2-ply and 4-ply cloth masks demonstrated elevated values in comparison to the 3-ply cloth mask or medical masks tested in this study. Likewise, layering a 3-ply cloth mask over a medical mask (double masking) noticeably increased airflow resistance. Airflow resistance, which is an ASTM standardized test that measures how breathable a mask is, has important implications with regards to user compliance. It should be noted that differences in filtration efficiency and airflow resistance were evident between the two medical face masks tested. Despite both masks consisting of 3 plies of material, medical mask 2 had a greater filtration efficiency and airflow resistance than medical mask 1 and performed better overall as a source control device when tested unmodified or fit modified. The materials used in the construction of medical mask 2 were more rigid and lent towards better facial contouring and, thus, source control performance, most notably when either toggles or the knotted and tucked ear loop modification were used to enhance the seal of the mask. Collectively, these empirical studies emphasize the importance of wearing a comfortable face mask that effectively filters respiratory particles and seals tightly to the face for optimal source control.

Humans continuously expel respiratory droplets and aerosols in a broad range of aerodynamic particles sizes. A recently published study has shown that larger respiratory droplets can travel up to 8 
medRxiv preprint doi: https://doi.org/10.1101/2021.09.16.21263642; this version posted September 26, 2021. The copyright holder for this preprint (which was not certified by peer review) is the author/funder, who has granted medRxiv a license to display the preprint in perpetuity. This article is a US Government work. It is not subject to copyright under 17 USC 105 and is also made available for use under a CCO license.

meters from an infected individual before settling onto surfaces, whereas smaller respiratory aerosols can remain airborne almost indefinitely. ${ }^{23}$ Limiting the expulsion of respiratory aerosols of any size from an infected source is critical for transmission control. Our respiratory simulator expels a test aerosol predominantly consisting of particles $\leq 7 \mu \mathrm{m}$ in size. Using two different methods of aerosol measurement, our simulation studies demonstrate that not all medical and cloth masks perform equally as source control devices. During cough simulations, as particle size increased above $3.3 \mu \mathrm{m}$, comparable collection efficiencies were observed between an unmodified and a fit modified face mask (cloth or medical), suggesting that larger particles were more likely to be filtered out by the mask compared with those under $3.3 \mu \mathrm{m}$. However, when looking at the smaller size fractions of the test aerosol produced during simulated coughs and exhalations, a shift in particle size distribution and collection efficiency was evident when a face mask was fit modified. When the fit of a medical face mask was modified with a brace or layered with a cloth mask (double masking), the collection efficiency improved for particles $\leq 3.3 \mu \mathrm{m}$ in size. A similar trend was observed when a cloth mask was secured with a brace. Because expelled respiratory particles are influenced by air flow dynamics, using a fit modification that reduces facial gaps along the nose and contours of the face is key for effective source control. However, additional aerosol simulation studies looking further at aerodynamic particle size distributions are warranted.

Several limitations exist with our study looking at the effect of masks and fit modifications on source control performance. Many different types of face masks are available for purchase. We tested three different cloth masks that varied in fabric composition and ply level and tested two different 3-ply medical masks composed of synthetic material of unknown formulation. Likewise, we tested seven different fit modifications and compared particle collection efficiencies with the equivalent unmodified face mask. As such, mask production-related inconsistencies may create minor discrepancies in the comparative analysis. Other limitations to our study entail the respiratory conditions used on the source 
medRxiv preprint doi: https://doi.org/10.1101/2021.09.16.21263642; this version posted September 26, 2021. The copyright holder for this preprint (which was not certified by peer review) is the author/funder, who has granted medRxiv a license to display the preprint in perpetuity. This article is a US Government work. It is not subject to copyright under 17 USC 105 and is also made available for use under a CCO license.

control system. For our cough simulation studies, we used a single cough flow profile that is based upon earlier studies that assessed cough volumes and flow rates from influenza patients. ${ }^{24}$ For the simulated exhalation studies, the International Organization for Standardization (ISO) standard for the ventilation rate for a female performing light work was selected. ${ }^{8}$ Coughing and breathing flow rates vary from person to person under different physiological conditions, and different flow rates could give different results. The composition of the test aerosol used in our simulation studies is not comparable to human respiratory aerosols nor is the test aerosol enveloped by a turbulent gas cloud that is typically generated during human expiratory events. ${ }^{25}$ Lastly, results from our experimental studies assume that the fluorescein dye used in aerosol particle quantification is homogenously distributed to $\mathrm{KCl}$ particles.

\section{CONCLUSIONS}

Our respiratory simulation studies examined the source control performance of medical and cloth face masks in conjunction with several fit modifications and identified practical combinations that improved mask seal and efficaciously blocked expelled aerosols from the source. Layering a 3-ply cloth mask over a medical mask (double masking) or securing a medical mask with an elastic brace improved fit and provided optimal source control performance. Further evaluation of mask source control performance through regression analysis would prove informative. The results of these studies have broad applicability towards personal measures that can be taken to reduce the transmission of respirable infectious pathogens and are not limited to the SARS-CoV-2 virus.

\section{DISCLAIMERS}

The authors declare no competing interests. The findings and conclusions in this report are those of the authors and do not necessarily represent the official position of the National Institute for Occupational Safety and Health, Centers for Disease Control and Prevention. Mention of any company or product 
medRxiv preprint doi: https://doi.org/10.1101/2021.09.16.21263642; this version posted September 26, 2021. The copyright holder for this preprint (which was not certified by peer review) is the author/funder, who has granted medRxiv a license to display the preprint in perpetuity. This article is a US Government work. It is not subject to copyright under 17 USC 105 and is also made available for use under a CCO license.

does not constitute endorsement by the National Institute for Occupational Safety and Health, Centers for Disease Control and Prevention.

\section{ACKNOWLEDGEMENTS}

We would like to thank our families for their support. This work was supported by the following sources: Centers for Disease Control and Prevention, National Institutes of Health R01 ES015022 (TRN) and WVCTSI U54 GM104942-05.

\section{REFERENCES}

1. Wang CC, Prather KA, Sznitman J, Jimenez JL, Lakdawala SS, Tufekci Z, et al. Airborne transmission of respiratory viruses. Science. 2021;373.

2. Prather KA, Marr LC, Schooley RT, McDiarmid MA, Wilson ME, Milton DK. Airborne transmission of SARS-CoV-2. Science. 2020;370:303-4.

3. Leung NHL. Transmissibility and transmission of respiratory viruses. Nat Rev Microbiol. 2021:118.

4. Wölfel R, Corman VM, Guggemos W, Seilmaier M, Zange S, Müller MA, et al. Virological assessment of hospitalized patients with COVID-2019. Nature. 2020;581:465-9.

5. CDC. Your Guide to Masks. Atlanta, GA: Centers for Disease Control and Prevention; 2021. p. https://www.cdc.gov/coronavirus/2019-ncov/prevent-getting-sick/about-face-coverings.html.

6. Joo H, Miller GF, Sunshine G, Gakh M, Pike J, Havers FP, et al. Decline in COVID-19 Hospitalization Growth Rates Associated with Statewide Mask Mandates - 10 States, MarchOctober 2020. MMWR Morbidity and Mortality Weekly Report. 2021;70:212-6.

7. Lyu W, Wehby GL. Community Use Of Face Masks And COVID-19: Evidence From A Natural Experiment Of State Mandates In The US. Health Aff (Millwood). 2020;39:1419-25.

8. Lindsley WG, Blachere FM, Law BF, Beezhold DH, Noti JD. Efficacy of face masks, neck gaiters and face shields for reducing the expulsion of simulated cough-generated aerosols. Aerosol Sci Technol. 2021:1-9.

9. Brooks JT, Beezhold DH, Noti JD, Coyle JP, Derk RC, Blachere FM, et al. Maximizing Fit for Cloth and Medical Procedure Masks to Improve Performance and Reduce SARS-CoV-2 Transmission and Exposure, 2021. MMWR Morbidity and Mortality Weekly Report. 2021;70:254-7.

10. Lindsley WG, Blachere FM, Beezhold DH, Law BF, Derk RC, Hettick JM, et al. A comparison of performance metrics for cloth masks as source control devices for simulated cough and exhalation aerosols. Aerosol Sci Technol. 2021:1-18.

11. ASTM. ASTM WK73471 New Specification for Barrier Face Coverings. West Conshohocken, PA USA: ASTM International; 2021.

12. Howard J, Huang A, Li Z, Tufekci Z, Zdimal V, van der Westhuizen HM, et al. An evidence review of face masks against COVID-19. Proc Natl Acad Sci USA. 2021;118:e2014564118.

13. Leung NHL. Transmissibility and transmission of respiratory viruses. Nat Rev Microbiol. 2021;19:528-45.

14. Brooks JT, Butler JC. Effectiveness of Mask Wearing to Control Community Spread of SARS-CoV2. JAMA. 2021;325:998-9. 
medRxiv preprint doi: https://doi.org/10.1101/2021.09.16.21263642; this version posted September 26, 2021. The copyright holder for this preprint (which was not certified by peer review) is the author/funder, who has granted medRxiv a license to display the preprint in perpetuity. This article is a US Government work. It is not subject to copyright under 17 USC 105 and is also made available for use under a CCO license.

15. CDC. Improve the Fit and Filtration of Your Mask to Reduce the Spread of COVID-19. Atlanta, GA: Centers for Disease Control and Prevention; 2021. p. https://www.cdc.gov/coronavirus/2019ncov/prevent-getting-sick/mask-fit-and-filtration.html.

16. Drewnick F, Pikmann J, Fachinger F, Moormann L, Sprang F, Borrmann S. Aerosol filtration efficiency of household materials for homemade face masks: Influence of material properties, particle size, particle electrical charge, face velocity, and leaks. Aerosol Sci Technol. 2021;55:6379.

17. Clapp PW, Sickbert-Bennett EE, Samet JM, Berntsen J, Zeman KL, Anderson DJ, et al. Evaluation of Cloth Masks and Modified Procedure Masks as Personal Protective Equipment for the Public During the COVID-19 Pandemic. JAMA Intern Med. 2020.

18. Rothamer DA, Sanders S, Reindl D, Bertram TH. Strategies to minimize SARS-CoV-2 transmission in classroom settings: combined impacts of ventilation and mask effective filtration efficiency. Sci Technol Built Environ. 2021:1-23.

19. OSHA. Additional Ambient Aerosol CNC Quantitative Fit Testing Protocols: Respiratory Protection Standard. In: Administration OSaH, editor. 84 FR 50739. Washington, DC: Occupational Safety and Health Administration; 2019. p. 50739-56.

20. Lindsley WG, Beezhold DH, Coyle J, Derk RC, Blachere FM, Boots T, et al. Efficacy of universal masking for source control and personal protection from simulated cough and exhaled aerosols in a room. J Occup Environ Hyg. 2021:1-14.

21. Honein MA, Christie A, Rose DA, Brooks JT, Meaney-Delman D, Cohn A, et al. Summary of Guidance for Public Health Strategies to Address High Levels of Community Transmission of SARS-CoV-2 and Related Deaths, December 2020. MMWR Morb Mortal Wkly Rep. 2020;69:1860-7.

22. Konda A, Prakash A, Moss GA, Schmoldt M, Grant GD, Guha S. Aerosol Filtration Efficiency of Common Fabrics Used in Respiratory Cloth Masks. ACS Nano. 2020;14:6339-47.

23. Fennelly KP. Particle sizes of infectious aerosols: implications for infection control. Lancet Respir Med. 2020;8:914-24.

24. Lindsley WG, Reynolds JS, Szalajda JV, Noti JD, Beezhold DH. A Cough Aerosol Simulator for the Study of Disease Transmission by Human Cough-Generated Aerosols. Aerosol Sci Technol. 2013;47:937-44.

25. Bourouiba L. Turbulent Gas Clouds and Respiratory Pathogen Emissions: Potential Implications for Reducing Transmission of COVID-19. JAMA. 2020;323:1837-8. 
medRxiv preprint doi: https://doi.org/10.1101/2021.09.16.21263642; this version posted September 26, 2021. The copyright holder for this preprint (which was not certified by peer review) is the author/funder, who has granted medRxiv a license to display the preprint in perpetuity.

This article is a US Government work. It is not subject to copyright under 17 USC 105 and is also made available for use under a CCO license.

Table 1. Source control devices and fit modifications evaluated during simulated cough and exhalation studies.

\begin{tabular}{|c|c|c|c|}
\hline Designation & Product Name & Brand & Description \\
\hline \multicolumn{4}{|l|}{ Source Control Devices } \\
\hline Medical mask 1 & $\begin{array}{l}\text { Disposable Protective } \\
\text { Mask }\end{array}$ & $\begin{array}{l}\text { Excellent } \\
\text { Artisan }\end{array}$ & $\begin{array}{l}\text { 3-ply medical face mask with } \\
\text { elastic earloops \& adjustable } \\
\text { metal nose strip }\end{array}$ \\
\hline Medical mask 2 & Disposable Surgical Mask & $\begin{array}{l}\text { Winner Medical } \\
\text { Co., Ltd. }\end{array}$ & $\begin{array}{l}\text { 3-ply medical face mask with } \\
\text { elastic earloops \& adjustable } \\
\text { metal nose strip }\end{array}$ \\
\hline 2-ply cloth mask & Reusable 2-ply Face Mask & $\begin{array}{l}\text { Lefty } \\
\text { Production, Co. }\end{array}$ & $\begin{array}{l}\text { 2-ply polyester blend face mask } \\
\text { with earloops }\end{array}$ \\
\hline 3-ply cloth mask & $\begin{array}{l}\text { Defender 3-ply Cotton } \\
\text { Mask }\end{array}$ & HanesBrands & $\begin{array}{l}\text { 3-ply } 100 \% \text { cotton face mask with } \\
\text { earloops \& adjustable metal nose } \\
\text { strip }\end{array}$ \\
\hline 4-ply cloth mask & Reusable 4-ply Face Mask & Badger-Smith & $\begin{array}{l}\text { 4-ply cotton-polyester blend face } \\
\text { mask with earloops \& adjustable } \\
\text { metal nose strip }\end{array}$ \\
\hline \multicolumn{4}{|l|}{ Fit Modifications } \\
\hline Earloops crossed & & & $\begin{array}{l}\text { Crossing the earloops to create a } \\
\text { loop that fits over the ear }\end{array}$ \\
\hline Mask bracket & $\begin{array}{l}\text { Cool Protection Stand 3D } \\
\text { Mask Bracket }\end{array}$ & Anbirong & $\begin{array}{l}\text { Reusable plastic mask bracket } \\
\text { worn under a face mask }\end{array}$ \\
\hline Earloop strap & $\begin{array}{l}\text { Adjustable Mask Ear } \\
\text { Strap Hook Extender }\end{array}$ & Maoxing Weiye & $\begin{array}{l}\text { Reusable plastic adjustable strap } \\
\text { worn behind the head to adjust } \\
\text { earloops }\end{array}$ \\
\hline Earloop toggle & $\begin{array}{l}\text { Silicone Elastic Mask } \\
\text { Adjustment Buckle }\end{array}$ & Beeager & $\begin{array}{l}\text { Silicone toggles used to adjust the } \\
\text { earloops }\end{array}$ \\
\hline Knotted \& tucked & & & $\begin{array}{l}\text { Knotting the earloops near the } \\
\text { mask panel with excess material } \\
\text { tucked under the knot }\end{array}$ \\
\hline Double masking & & & $\begin{array}{l}\text { A 3-ply } 100 \% \text { cotton cloth mask } \\
\text { worn over a medical face mask }\end{array}$ \\
\hline Mask brace & Mask brace & Fix the Mask & $\begin{array}{l}\text { Reusable elastic brace worn over a } \\
\text { mask }\end{array}$ \\
\hline
\end{tabular}


medRxiv preprint doi: https://doi.org/10.1101/2021.09.16.21263642; this version posted September 26, 2021. The copyright holder for this preprint (which was not certified by peer review) is the author/funder, who has granted medRxiv a license to display the preprint in perpetuity.

This article is a US Government work. It is not subject to copyright under 17 USC 105 and is also made available for use under a CCO license.

Table 2. Human and manikin mask fit factors evaluated during mask fit tests using a PortaCount ${ }^{\circledR}$ Pro+ (TSI).

\begin{tabular}{|c|c|c|c|c|c|}
\hline \multirow[t]{2}{*}{ Face Covering } & \multirow[t]{2}{*}{ Modification } & \multicolumn{2}{|c|}{ Human Fit Factor } & \multicolumn{2}{|c|}{ Manikin Fit Factor } \\
\hline & & mean & $S D$ & mean & $S D$ \\
\hline \multirow[t]{8}{*}{ Medical mask 1} & No modification & 1.6 & 0.5 & 2.0 & 0.2 \\
\hline & Crossed & 1.1 & 0.2 & 2.2 & 0.4 \\
\hline & Bracket & 1.0 & 0.0 & 2.3 & 0.1 \\
\hline & Strap & 5.4 & 3.2 & 2.9 & 0.4 \\
\hline & Toggle & 4.0 & 2.0 & 4.1 & 0.6 \\
\hline & Knotted \& tucked & 6.0 & 1.5 & 4.0 & 0.9 \\
\hline & Double mask & 4.2 & 2.6 & 6.7 & 2.0 \\
\hline & Brace & 7.2 & 1.0 & 6.1 & 2.0 \\
\hline \multirow[t]{8}{*}{ Medical mask 2} & No modification & 1.8 & 0.4 & 2.9 & 0.7 \\
\hline & Crossed & 1.1 & 0.2 & 2.3 & 0.6 \\
\hline & Bracket & 1.6 & 0.5 & 2.2 & 0.1 \\
\hline & Strap & 3.3 & 1.2 & 3.1 & 0.6 \\
\hline & Toggle & 6.0 & 5.8 & 5.3 & 1.6 \\
\hline & Knotted \& tucked & 6.3 & 3.6 & 4.8 & 0.7 \\
\hline & Double mask & 2.1 & 1.1 & 7.0 & 2.9 \\
\hline & Brace & 13.3 & 3.7 & 7.2 & 1.3 \\
\hline \multirow[t]{2}{*}{ 2-ply cloth mask } & No modification & 1.4 & 0.3 & 1.5 & 0.0 \\
\hline & Brace & $2.0+$ & 0.0 & 2.0 & 0.3 \\
\hline \multirow[t]{2}{*}{ 3-ply cloth mask } & No modification & 1.3 & 0.5 & 1.5 & 0.1 \\
\hline & Brace & 2.0 & 0.0 & 2.1 & 0.3 \\
\hline \multirow[t]{2}{*}{ 4-ply cloth mask } & No modification & 1.5 & 0.6 & 2.6 & 0.5 \\
\hline & Brace & $4.6 \dagger$ & 1.5 & 3.6 & 0.7 \\
\hline
\end{tabular}

tFit factor was determined to be statistically significant $(p<0.05)$ when comparing a fit modified face mask to the corresponding no modification control. 
medRxiv preprint doi: https://doi.org/10.1101/2021.09.16.21263642; this version posted September 26, 2021. The copyright holder for this preprint (which was not certified by peer review) is the author/funder, who has granted medRxiv a license to display the preprint in perpetuity.

This article is a US Government work. It is not subject to copyright under 17 USC 105 and is also made available for use under a CCO license.
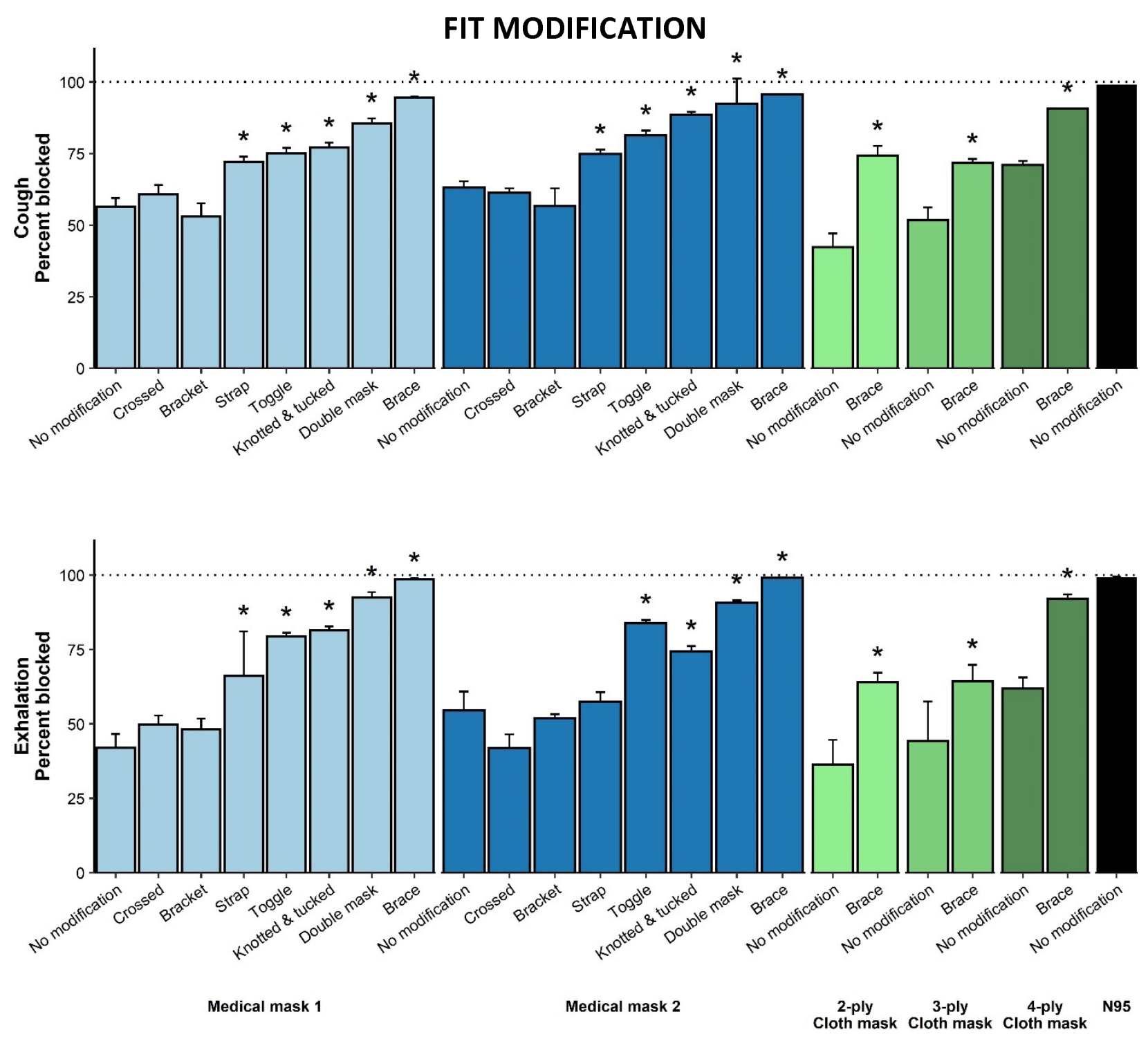

Figure 1. Source control performance of face masks (denoted by colors) with and without fit modifications. For comparison, source control data for an N95 respirator was included. Total particles blocked (\%) by medical and cloth face masks with and without fit modifications following cough (top) and exhalation (bottom) simulations. Percentage blocked is based on mass of particles collected following unmasked source coughing and exhalation experiments. Asterisks $\left({ }^{*}\right)$ indicate the modification was determined to be statistically significant $(p<0.05)$ compared to the corresponding no modification control. 


\section{FIT MODIFICATION}
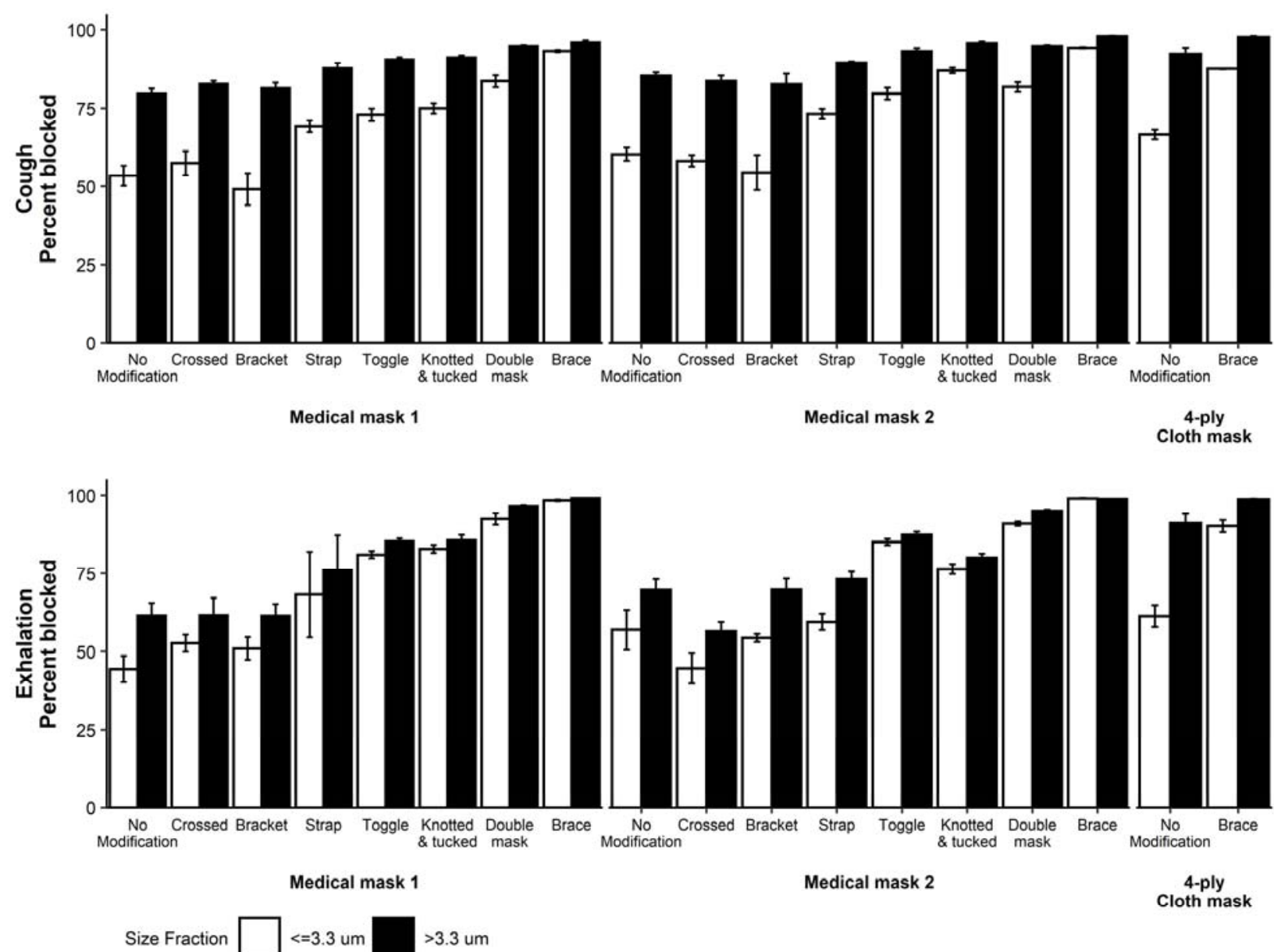

Figure 2. Percentage of particles in size fractions less and greater than $3.3 \mu \mathrm{m}$ blocked by face masks with and without fit modifications. Particles blocked (\%) in the size fraction $\leq 3.3 \mu \mathrm{m}$ (white bars) and the size fraction $>3.3 \mu \mathrm{m}$ (black bars) following cough (top) and exhalation (bottom) simulations. 
medRxiv preprint doi: https://doi.org/10.1101/2021.09.16.21263642; this version posted September 26, 2021. The copyright holder for this preprint (which was not certified by peer review) is the author/funder, who has granted medRxiv a license to display the preprint in perpetuity.

This article is a US Government work. It is not subject to copyright under 17 USC 105 and is also made available for use under a CCO license.

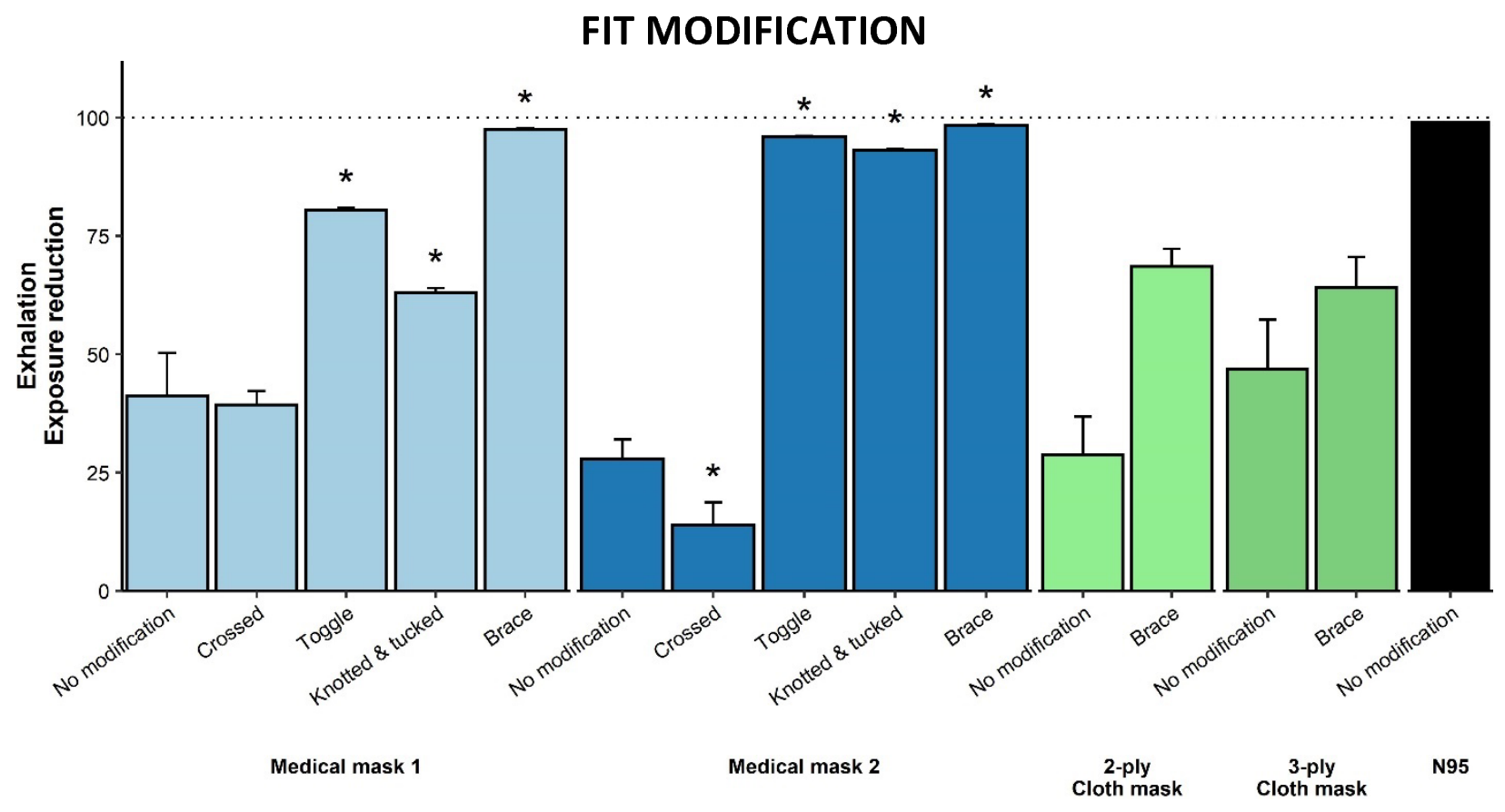

Figure 3. Exposure reduction (\%) resulting from source masking (denoted by colors) in environmental chamber exhalation studies using both source and recipient respiratory simulators. Percent reduction is based on recipient exposures following unmasked source exhalation simulations. For comparison, expsoure reduction data for an N95 respirator was included. Asterisks $\left({ }^{*}\right)$ indicate the modification was determined to be statistically significant $(p<0.05)$ compared to the corresponding no modification control. 